plants associated with similar peas showed no measurable uptake of nitrogen, confirming that the excretion was small.

Mr. J. Boyes collaborated in some of this work.

Dept. of Botany.

G. BOND.

University,

Glasgow.

Sept. 10.

${ }^{1}$ Bond, NATURE, 139, 675 (1937).

2 Virtanen, J. Soc. Chem. Ind., 54, 1015 (1935).

Bond, Ann. Bot., 50, 559 (1936)

Ludwig and Allison, J. Bact., 31, 93 (1936).

Wilson, NATURE, 140, 154 (1937).

\title{
Attitude and Concealing Coloration
}

I FOLLOWED with much interest and amusement a controversy in NATURE concerning the origin of species, which involved the meaning of protective coloration in insects. One correspondent asserted that insects placed themselves in special locations with which their concealment devices blended. I am submitting a further example of this.

We have in New Zealand a tree-lily or palm-lily, Cordyline australis, related to the dragon-trees, and known to us as the cabbage-tree. A looper caterpillar lives in and on its green erect crown, and the moth, Venusia verriculata, from this caterpillar lies concealed by day in the dead, strap-like leaves that hang like a rustling skirt around the trunk.

Other observers have noted that

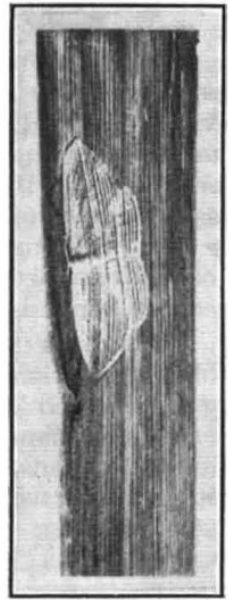

Fig. 1.

Venusia verriculata RESTING ON DEAD LEAF OF THE' 'CABBAGE TREE'. APPROX. $\frac{2}{3}$ NATURAL SIZE

they match very well in colour. whenever they have found the moth thus at rest, it was so oriented on the leaf that its brown parallel markings lay along the parallel veins of the dead monocotyledonous leaf. But last summer $I$ was lucky in finding so many on one particular tree that I could stir them up with a straw, and observe that whether they flew or just crept to another leaf, they always, after a few compass-like vacillations, lay down finally with the body across the leaf, so placing wing-lines along leaf-veins. The body is pressed very close, and the antennæe bent in under the forewings. The moth in the photograph (Fig. 1) was coaxed on to a length of leaf, and moved into a prefocused position. It has not closed its wings quite as perfectly as usual, but it can be seen that their lines would otherwise be continued straight across thorax and abdomen and just about parallel with the leaf-veins, which

This is, so far as I can find, the first time the actual movement, appearing strikingly purposive, has been observed, or even the live insect photographed more or less in situ.

Dominion Laboratory,

Scientific and Industrial

Research Department, Wellington.

Aug. 5.
THE part played by living insects in adopting attitudes which increase the effect of the colour and pattern is often overlooked in discussing the relation of coloration of insects to natural selection. $\mathrm{Mr}$. J. J. S. Cornes has given a striking new example from New Zealand of a phenomenon recorded by by Mr. A. H. Hamm ${ }^{1}$, for English moths when resting on the bark of trees. It was recorded that the vast majority of the individuals of the common winter moth, Hybernia leucophearia, rest with the body horizontal, so that the lines of pattern on the wings are brought into parallelism with the dark shadows in the abundant vertical cracks of the bark on which they rest. If the wings were spread horizontally, as is so often the case with moths of this group, the main lines of the pattern would cut across the main lines of the background.

The same principle was shown to apply to the resting attitudes of other species in a later paper ${ }^{2}$. It is quite obvious when one witnesses such a case that the insect is under the influence of a strong instinct and that until it has adopted the attitude described it is uneasy. The same thing has often been noted with the butterfly Eronia cleodora in Africa, of which the underside resembles the blotched green, yellow and brown appearance of a partially dead leaf ${ }^{3}$. Specimens disturbed from rest among vegetation have been seen to settle among the leaves on a plant which show the same mottled coloration rather than among healthy and entirely green leaves.

G. D. Hale Carpenter.

Department of Entomology,

University Museum, Oxford.

${ }^{1}$ Proc. Ent. Soc. Lond., p. xv (March 19, 1902).

2 Trans. Ent. Soc. Lond., 483-85, Plate xxix (1906).

${ }^{3}$ Longstaff, G. B., "Butterfly Hunting in Many Lands" (London, 1912), p. 194 and frontispiece.

\section{Excretion of Vitamin C in Sweat}

ON the Witwatersrand gold mines, where the Bantu mine labourers work under hot humid conditions, cases of scurvy and sub-scurvy occur with some frequency, despite the fact that the diet provided has been shown to contain adequate amounts of vitamin C (some 20-30 mgm. daily). The explanation given is that the high energy requirement increases utilization of the vitamin. However, on testing sweat samples collected from recruits undergoing a 'heat tolerance' test under conditions approaching those encountered underground (shovelling gravel at $97^{\circ} \mathrm{F}$. dry and $96^{\circ} \mathrm{F}$. wet bulb for one hour in a surface chamber), it was found that sweat reduced indophenol dye under conditions regarded as specific for the vitamin 1 .

The vitamin $\mathrm{C}$ content of a series of samples varied between $0.5 \mathrm{mgm}$. and $1.1 \mathrm{mgm}$. ascorbic acid per 100 c.c. Since the average weight loss during the test is about $\frac{1}{2} \mathrm{lb}$., representing chiefly sweat loss, excretion of vitamin $C$ by this route amounts to some $2 \mathrm{mgm}$. per hour. Further, examination of the urinary excretion of vitamin $\mathbf{C}$ both before and after the heat chamber shows no change. Hence severe exercise produces an increased elimination through the sweat mechanism.

We found ${ }^{2}$ that the average urinary excretion of Bantu miners was $10 \mathrm{mgm}$. vitamin $\mathrm{C}$ daily and did not differ from boys resting. As Orenstein ${ }^{3}$ has shown that a miner may lose $2 \frac{1}{2}-5 \mathrm{lb}$. weight after 